\title{
EXTERNAL DEBT, INSTITUTIONAL QUALITY AND ECONOMIC GROWTH
}

\author{
Siti Nurazira Mohd Daud \\ School of Economic, Finance and Banking, Universiti Utara Malaysia, Malaysia. \\ Email:sitinurazira@uum.edu.my
}

\begin{abstract}
This paper examines the role of institutional quality in the external debt-economic growth relationship. By taking a dynamic threshold specification to a panel data consisting of 53 countries, we find that external debt has an adverse effect on a country's growth, while institutional quality improves it. We find that the effect of external debt on economic growth depends on the level of institutional quality. In addition, at a high level of external debt, the effect of institutional quality on growth is very small, suggesting that the adverse effect of external debt on a country's economic growth holds true.
\end{abstract}

Keywords: External debt; Economic growth; Institutional quality; Emerging economies. JEL Classifications: F43; F34; C32; O40.

\author{
Article history: \\ Received : October 17, 2019 \\ Revised : : December 18, 2019 \\ Accepted : February 09, 2020 \\ Available online : February 09, 2020 \\ https://doi.org/10.21098/bemp.v23i2.1173
}




\section{INTRODUCTION}

External debt is an important initiative for capital formation in the Solow growth model, which explained why countries borrow from abroad (Villaneuva, 2003; Otani and Villanueva, 1989). The early work of Griffin and Enos (1970) highlighted that external debt may enhance economic growth only to a certain point. Global debt (both public and private) has reached an all-time high, while emerging market public debt is at levels last seen during the 1980s debt crisis and low-income countries are experiencing a sharp increase in their debt burden (IMF, 2019). This high debt burden potentially represents a risk to economies having implications for financial stability and crowding out investment.

However, to-date, there is a lack of consensus in the literature on the effect of external debt on a country's economic growth. There is a considerable literature supporting a negative effect of external debt on a country's economic growth (Cordella et al., 2010; Pattillo et al., 2011; Ramzan and Ahmad, 2014; Daud and Podivinsky, 2012; Pattillo et al., 2004; Chowdhury, 2001; Sen et al., 2007). ${ }^{1}$ In contrast, Pattillo et al. (2002, 2004), Cordella et al. (2010), and Imbs and Ranciere (2005) find that the effect of external debt on growth is positive up to a certain limit of external debt.

Thus, no clear consensus exists on the relationship between external debt and economic growth. Despite this lack of consensus, managing debt is critical, since it also involves risks and costs, and paying-off debt simultaneously. Seminal work on the sources of growth, including the Solow model, and the endogenous growth model and its extensions, assume that distributive policies and institutional quality are in place for income to converge (Law et al., 2018; Daud and Podivinsky, 2014; Law et al., 2013). Relevant institutions playing their role in the regulatory framework could lower the probability of a debt overhang (Imbs and Ranciere, 2005). The challenges one might highlight in debt initiatives are the quality of the political environment, government legislation, institutional framework, and delivery of basic services (IMF, 2013). ${ }^{2}$ In addition, Pattillo et al. (2004) explained that the main channel through which debt affects economic growth is the quality and efficiency of investment rather than its level. Meanwhile, the quantity and productivity of inputs, be they capital or labor, will be influenced by the institutional environment (Gwartney et al., 2004). One might wonder whether or not the environment and the institutions, including economic freedom, complement the impact of debt on economic growth. ${ }^{3}$ This could be translated to the potentially important factors explaining the adverse effect of debt on growth, which could be summed up as the quality of policy and institutions. On the other hand, the institutional quality

\footnotetext{
1 The adverse effect of external debt on growth may be related to debt overhang and the crowding-out effects, whereby external debts are excessively high and associated with a low ability. A high debt levels are likely to discourage of foreign investment.

2 One important lesson learned from the recent global financial crisis 2007-2008 is that prudent macroeconomic policies should be supported by a political environment and relevant government legislation conducive to boosting the domestic economy (UNECA, 2012). In addition, Alfaro et al. (2004) point out the importance of local conditions (such as expropriation risk) in facilitating the effect of capital flows to a country.

3 There are studies showing a positive relationship between economic freedom and growth (see, e.g., Gwartney et al., 2004; Dawson, 2003; Heckelman and Stroup, 2000; Heckelman, 2000).
} 
of a country has a significant and positive effect on the level of long-term debt on a firm's financial structure, thus suggesting that it is an important determinant of corporate financing and debt maturity (Kirch et al., 2012).

Research in this area has started to investigate the role played by institutional quality on the effect of external debt on growth (Mensah et al., 2018; Cordella et al., 2010; Imbs and Ranciere, 2005). Focusing on highly indebted countries over the period from 1970 to 2002, Cordella et al., (2010) find that countries with good policies and institutions still experience negative effects of external debt (a strong debt overhang position), if countries held debt in excess of $25 \%$ of gross domestic product (GDP). In a country with bad policies, the debt threshold is lower, but the evidence of debt overhang is weaker (Cordella et al., 2010). Thus, no conclusion can be made regarding the external debt-economic growth nexus using this study. Meanwhile, Imbs and Ranciere (2005) find that a debt overhang is less likely to occur with more effective governance and within a better legal and contractual environment. However, a debt overhang might still happen at a higher level of indebtedness. A recent study by Mensah et al. (2018), in the context of 36 SubSaharan African countries, supports the existing evidence that the impact of external debt on growth is through countries' institutional quality, but only up to a point. In other words, when a country is on the wrong side of the debt Laffer curve, external debt and institutional quality becomes irrelevant (Mensah et al., 2018). However, the paper does not suggest the cut-off of debt on the debt Laffer curve.

Table 1 provides a summary of previous literature on the role of institutional quality in the debt-growth relationship. Hypothetically, good institutional quality would act as an accelerator to growth. In addition, the quality of institutions may impact the effect of debt on growth through the efficient allocation and responsible use of debt. As such, this paper extends prior studies by covering a large group of countries comprised of a longer sample period. We use a robust estimation method that sheds lights on the role of institutional quality in the effect of external debt on a country's growth and the optimal level of external debt a country should hold. Although several studies investigate the effect of foreign investment flow on growth, little attention is paid to the effect of external debt and institutional quality on growth. We make small but important contributions to the external debt-growth literature by investigating the effect of external debt on growth conditional on institutional quality. The recent rise in global uncertainty and the associated disruptions in economic activity, following the novel coronavirus outbreak, highlight the importance of understanding the sources of growth in order to better optimize growth policies. ${ }^{4}$ Countries completely locked down to minimize the spread of the coronavirus (see Iyke, 2020a; Phan and Narayan, 2020), which would worsen their ability to service their debts and potentially harm their ability to borrow in the future to invest in growth-oriented projects. In this regard, understanding the impact of external debt on growth is important. In addition, we

\footnotetext{
${ }_{4}$ A growing number of studies show the novel coronavirus outbreak made markets very volatile and disrupted global economic activity in various ways (see, e.g., Devpura and Narayan, 2020; Fu and Shen, 2020; Haroon and Rizvi, 2020; Iyke, 2020a,b; Mishra et al., 2020; Narayan, 2020; Phan and Narayan, 2020; Prabheesh et al., 2020; Salisu and Adediran, 2020; Salisu and and Akanni, 2020; Vidya and Prabheesh, 2020).
} 
extend the literature by employing the dynamic panel threshold regression method of Kremer et al. (2013) to explore the non-linear relationship between external debt and economic growth, and we estimate the threshold values of external debt and institutional quality on economic growth.

Table 1.

Summary of the Studies Between External Debt, Institutional Quality, and Economic Growth

This table present the current literature that investigate the relationship between external debt, institutional quality and economic growth.

\begin{tabular}{|c|c|c|c|c|}
\hline Authors & $\begin{array}{l}\text { Sample } \\
\text { countries }\end{array}$ & $\begin{array}{l}\text { Type of data } \\
\text { and sample } \\
\text { period }\end{array}$ & Methods & Findings \\
\hline $\begin{array}{l}\text { Cordella et } \\
\text { al., (2010) }\end{array}$ & $\begin{array}{c}79 \text { developing } \\
\text { countries }\end{array}$ & $\begin{array}{l}\text { Panel data } \\
(1970-2002)\end{array}$ & $\begin{array}{c}\text { System- } \\
\text { Generalized } \\
\text { methods of } \\
\text { moments }\end{array}$ & $\begin{array}{l}\text { The quality of institutions matters } \\
\text { to the external debt-growth } \\
\text { relationship depending on the level } \\
\text { of external debt. Countries with } \\
\text { good policies and institutions face } \\
\text { overhang when NPV of external } \\
\text { debt rises above } 20-25 \text { percent of } \\
\text { GDP, while in countries with bad } \\
\text { policies and institutions, overhang } \\
\text { and irrelevance thresholds seem to } \\
\text { be substantially lower (10-15 and } \\
\text { 15-35 percent of GDP, respectively). }\end{array}$ \\
\hline
\end{tabular}

\begin{tabular}{|c|c|c|c|}
\hline $\begin{array}{l}\text { Imbs and } \\
\text { Ranciere } \\
\text { (2005) }\end{array}$ & $\begin{array}{l}87 \text { low and } \\
\text { middle } \\
\text { income } \\
\text { countries. }\end{array}$ & $\begin{array}{c}\text { Panel data } \\
\text { (1969-2002) }\end{array}$ & $\begin{array}{c}\text { System- } \\
\text { Generalized } \\
\text { methods of } \\
\text { moments }\end{array}$ \\
\hline
\end{tabular}

Institutions matter in the external debt-growth relationship.

Government effectiveness, the rule of law and bureaucratic quality correlate positively with economic growth and tend to limit external debt build-up.

In addition, external debt overhang occurs when the face value of external debt reaches 55 to 60 percent of GDP or 200 percent of exports, or when the present value of external debt reaches 35 to 40 percent of GDP or 140 percent of exports. However, external debt overhang may still happen in economies endowed with good institutions, but for higher values of external debt.

\begin{tabular}{|c|c|c|c|c|}
\hline $\begin{array}{l}\text { Mensah et al. } \\
(2018 b)\end{array}$ & $\begin{array}{c}36 \text { Sub- } \\
\text { Saharan } \\
\text { Africa }\end{array}$ & $\begin{array}{l}\text { Panel data } \\
(1996-2013)\end{array}$ & $\begin{array}{l}\text { System- } \\
\text { Generalized } \\
\text { methods of } \\
\text { moments }\end{array}$ & $\begin{array}{l}\text { The results from the system-GMM } \\
\text { found that institutional quality } \\
\text { has robust effects on the external } \\
\text { debt-growth nexus. However, the } \\
\text { mediating effect of institutional } \\
\text { quality on this nexus is up to an } \\
\text { optimal level of the external debt- } \\
\text { Laffer curve. }\end{array}$ \\
\hline
\end{tabular}


Based on a panel data consisting of 53 countries over the period of 2005-2016, we show that external debt has an adverse effect on a country's growth, while institutional quality improves it. We show that the coefficient of the interaction between external debt and institutional quality is statistically significant with a negative sign, implying that the effect of external debt on economic growth depends on the level of institutional quality. In addition, at a high level of external debt, the effect of institutional quality on growth is very small, suggesting that the adverse effect of external debt on a country's economic growth holds true.

The paper is structured as follows. The next section reviews the data and methodology. Section III presents the empirical results, while Section IV concludes the paper.

\section{MODEL, METHODOLOGY AND DATA}

This paper follows the standard growth literature to investigate the external debtgrowth relationship by specifying the empirical model as:

$$
\text { GROWTH } H_{i t}=\beta^{\prime} E D_{i t}+\gamma X_{i t}+\varepsilon_{i t}
$$

where GROWTH $H_{i t}$ is economic growth measured as the growth rate in GDP per capita, $E D_{i t}$ is country $i$ 's external debt level, $X_{i t}$ is a vector of control variables used in the growth literature, namely initial income, investment-gross domestic product ratio, population growth rates, trade, and institutional quality (see Cordella et al., 2010; Iyke, 2017, 2018; Takumah and Iyke, 2017; Juhro et al., 2020; Ho and Iyke, 2020), $\varepsilon_{i t}$ is the error term, $i=1, \ldots N$ is the country identifier, and $t=1, \ldots T$ is the time identifier. The institutional quality indicator is measured using the country external debt policy, economic management cluster, and macroeconomic management indicators published by the World Bank, which are developed to assess the quality of a country's present policy and institutional framework. For each criterion, countries are rated on a scale of 1 to 6 , such that a 1-rating implies a very weak performance and a 6-rating implies a very strong performance. The Country Policy and Institutional Assessment (CPIA) consists of 16 criteria, which are grouped into four clusters. This paper focuses on one of the CPIA clusters, namely economic management. The economic management cluster includes macroeconomic management, fiscal policy, and debt policy. The debt policy management assesses whether the external debt management strategy is conducive to minimizing budgetary risks and ensuring long-term external debt sustainability. Macroeconomic management assesses the monetary, exchange rate, and aggregate demand policy frameworks. We choose this cluster because the quality of economic management would possibly affect the role played by external debt on a country's growth, since external debt consists of a government's external debt. In addition, economic management plays a role in facilitating the business eco-system, thus enhancing the efficiency or productivity of external debt. Investment ratio and population growth represent physical and human capital accumulation, respectively. ${ }^{5}$ The model used to estimate the impact of institutional quality on the external debt-growth relationship is as follows:

5 A list of countries is presented in Appendix 1. 


$$
\text { GROWTH }_{i t}=\beta_{1} E D_{i t}+\beta_{2} I Q_{i t}+\beta_{3}\left(E D_{i t} * I Q_{i t}\right)+\gamma X_{i t}+\mu_{i}+\theta_{t}+\varepsilon_{i t}
$$

where $\mu_{i^{\prime}} \theta_{t^{\prime}}$ and $\varepsilon_{i t}$ represent the country-specific effect, time effect, and the white-noise error term. The coefficient associated with $\beta_{3}$ captures the effect of institutions on the external debt-growth relationship. In other words, the interaction variable, $E D_{i t}{ }^{*} I Q_{i{ }^{\prime}}$ captures the idea that institutional factors may explain the variation in the external debt-growth nexus. ${ }^{6}$

We employed the system Generalized Method of Moments (GMM) estimator proposed by Holtz-Eakin et al. (1988) to estimate Eq. (2). A general dynamic panel model for country $i$ at time $t$ is:

$$
Y_{i t}=\delta Y_{i t-1}+X_{i t} \beta_{1}+X_{i t} \beta_{2}+\ldots \ldots .+\varphi_{i}+\varepsilon_{i t}
$$

where $\varphi_{\mathrm{i}}$ is the vector of country effect, $X_{i t}$ is an $N \times p$ matrix of $p$ explanatory variables, and $e_{i t}$ is the error term, which is assumed to be normally distributed. A common approach to estimating a dynamic panel data model in the first difference GMM estimator, which was proposed by Arellano and Bond (1991), and can be formulated as:

$$
\Delta Y_{i t}=\delta \Delta Y_{i t-1}+\Delta X_{i t} \beta_{1}+\Delta X_{i t} \beta_{2}+\ldots \ldots+\varphi_{i}+\Delta \varepsilon_{i t}
$$

The idea of this estimator is to take the first differences of the variables in order to eliminate the source of inconsistency (i.e. the country-specific effect $\varphi_{i}$,), and use the levels of the explanatory variables lagged at least two periods as instruments (see Arellano and Bond, 1991). For the first difference GMM estimators to be consistent, we must assume that the errors are not second-order serially correlated and that explanatory variables are weakly exogenous. However, Blundell and Bond (1998) pointed out that when explanatory variables are persistent, the lagged levels of the explanatory variables are weak instruments for the variables in differences. They showed that, in a small sample, the shortcomings of weak instruments translate into a large finite sample bias. By adding (3) into the original equation (4), a level of a system of equations that also include variables in the first differences, the system GMM estimator is particularly useful in controlling for country-specific effects. Additionally, the system GMM estimator preserves the cross-country dimension of the data that is lost when only the first differenced equation is estimated (Arellano and Bover, 1995; Blundell and Bond, 1998).

In the system GMM estimator, the equations in the first differences eliminate the fixed effects in the model. Moreover, the difference equations are combined with equations in levels, which are instrumented with the lagged first differences of the corresponding explanatory variable. In other words, the system GMM estimator controls for the potential endogeneity of all explanatory variables by using the instrumental variables. In order to use these additional instruments, we need the identifying assumption that the first difference of the explanatory variables is not correlated with the explanatory variables; the correlation is supposed to be constant over time. If the moment conditions are valid, Blundell

${ }_{6}$ However, our model and number of countries are constrained by the data unavailiability. 
and Bond (1998) showed, in Monte Carlo simulations, that the system GMM estimator performs better than the first difference GMM estimator. We can test the validity of the moment conditions by using the conventional test of overidentifying restrictions proposed by Sargan (1958), testing the null hypothesis to verify that the error term is not second-order serially correlated. The system GMM estimator has several advantages when estimating the growth model. By taking the first difference approach to remove the unobserved time-invariant, countryspecific effects, the system GMM estimator eliminates omitted variable bias that are constant over time (Bond et al., 2001). In addition, the use of instrumental variables allows the parameters to be consistently estimated, which eliminates the potential endogeneity problem as well as measurement errors.

We carried out robustness checks to examine the sensitivity of our results to additional estimation strategies and methods. We employed the dynamic panel threshold regression method by Kremer et al. (2013) to explore the non-linear relationship between external debt and economic growth. In addition, we used this method to estimate the threshold values of external debt and institutional.

Kremer et al. (2013) extended Hansen's (1999) static panel threshold estimation and Caner and Hansen's (2004) cross-sectional instrumental variable (IV) threshold model, using a GMM-type estimator to control for endogeneity. The threshold regression model is as follows:

$$
\begin{aligned}
\text { GROWTH }_{i t}=\mu_{i} & +\beta_{1} E D_{i t} I\left(E D_{i t} \leq \lambda\right)+\delta_{1} I\left(E D_{i t} \leq \lambda\right) \\
& +\beta_{2} E D_{i t} I\left(E D_{i t}>\lambda\right)+\gamma X_{i t}+\theta_{t}+\varepsilon_{i t}
\end{aligned}
$$

where $E D$ is the threshold variable and $\lambda$ is the unknown threshold parameter. In the following model $I Q$ is the threshold variable:

$$
\begin{aligned}
\text { GROWTH }_{i t}=\mu_{i} & +\beta_{1} E D_{i t} I\left(I Q_{i t} \leq \lambda\right)+\delta_{1} I\left(I Q_{i t} \leq \lambda\right) \\
& +\beta_{2} E D_{i t} I\left(I Q_{i t}>\lambda\right)+\gamma X_{i t}+\theta_{t}+\varepsilon_{i t}
\end{aligned}
$$

$\mathrm{I}()$ is the indicator function, which takes the value 1 if the argument in parenthesis is valid and 0 otherwise. This allows the role of external debt on a country's economic growth to differ depending on whether ED or IQ is below or above some unknown level of $\lambda$. The impact of external debt on growth is captured by $\beta_{1}$ and $\beta_{2}$ for low and high regimes, respectively. This method allows for a difference in regime intercept $\left(\delta_{1}\right)$.

We estimate Eq. (6) using the least squares estimator for a fixed threshold $\lambda$, where the endogenous variables are replaced by the predicted values in the reduced form regression. We then choose the threshold value $\lambda$ based on the smallest sum of squared residuals. After estimating the threshold value $\hat{\lambda}$, we estimate the slope coefficient using the GMM estimator. The critical values for determining the 95 percent confidence interval of the threshold value are given by:

$$
\Gamma=\{\lambda: L R(\lambda) \leq C(\alpha)\}
$$

where $C(a)$ is the 95 percentiles of the asymptotic distribution of the likelihood ratio statistics $L R(\lambda)$ Data are collected from various sources, including the World Development Indicators (WDI) and Country Policy and Institutional Assessment 
(CPIA) databases hosted by the World Bank. The sample consists of 53 countries and covers the period from 2005 to 2016 . $^{7}$

\section{RESULTS}

Table 2 presents descriptive statistics on the variables over the period of 2005 to 2016. The information derived from the descriptive statistics provides an overview of a country's position in the sample. The average growth rate of GDP per capita shows is $3.04 \%$ with a standard deviation of $3.46 \%$. Meanwhile, the average external debt per Gross National Income (GNI) is approximately 43.37. The averages of the three institutional quality in indicators (external debt policy, economic management cluster, and macroeconomics management) are, respectively, 3.62, 3.65, and 3.81. Since institutional quality is measured such that 1 and 6 imply low and high institutional quality, respectively, this means, on average, institutional quality is moderatein these countries.

Table 2.

\section{Descriptive Statistics, 2005-2016}

This table present descriptive statistics (namely, mean, standard deviation (SD), minimum (min.) and maximum (max.) values) for the 2005-2016 period. The variables noted in column 1 are growth rate of GDP per capita, initial income, investment, population, trade, external debt and institutional indicators (namely, external debt policy, economic management and economic management cluster). In addition, the measurement and source of the data are displayed in the last two columns.

\begin{tabular}{|c|c|c|c|c|c|c|}
\hline $\begin{array}{l}\text { Variables } \\
\text { (abbreviation) }\end{array}$ & Mean & SD & Min. & Max. & Measurement & $\begin{array}{c}\text { Source of } \\
\text { data }\end{array}$ \\
\hline $\begin{array}{l}\text { Growth Rate of GDP per } \\
\text { Capita }(G R O W T H)\end{array}$ & 3.04 & 3.64 & -22.23 & 18.00 & $\begin{array}{l}\text { Annual percentage } \\
\text { growth rate gross } \\
\text { domestic product per } \\
\text { capita in constant } 2010 \\
\text { U.S. dollars. }\end{array}$ & $\begin{array}{c}\text { WDI, } \\
\text { World } \\
\text { Bank }\end{array}$ \\
\hline Initial Income & 1484.67 & 1313.78 & 218.28 & 8221.77 & $\begin{array}{c}\text { Lagged of gross domestic } \\
\text { product per capita } \\
\text { in constant } 2010 \text { U.S. } \\
\text { dollars. }\end{array}$ & $\begin{array}{c}\text { WDI, } \\
\text { World } \\
\text { Bank }\end{array}$ \\
\hline Investment & 24.64 & 8.67 & 5.46 & 68.02 & $\begin{array}{l}\text { Gross capital formation } \\
\text { as percentage of GDP }\end{array}$ & $\begin{array}{c}\text { WDI, } \\
\text { World } \\
\text { Bank }\end{array}$ \\
\hline Population Growth & 2.04 & 1.07 & -1.32 & 3.94 & $\begin{array}{l}\text { Annual growth (in } \\
\text { percent) }\end{array}$ & $\begin{array}{c}\text { WDI, } \\
\text { World } \\
\text { Bank }\end{array}$ \\
\hline Trade & 78.87 & 32.15 & 19.10 & 203.83 & As percentage of GDP & $\begin{array}{c}\text { WDI, } \\
\text { World } \\
\text { Bank }\end{array}$ \\
\hline External Debt $(E D)$ & 43.37 & 29.38 & 1.98 & 231.99 & As percentage of GNI & $\begin{array}{c}\text { WDI, } \\
\text { World } \\
\text { Bank }\end{array}$ \\
\hline
\end{tabular}

7 Data on governance indicators are only available for the year 2005 onwards. Due to short sample size, the analysis is based on non-averaged 5-year data, as is the usual approach conducted in growth literature. 
Table 2.

Descriptive Statistics, 2005-2016 (Continued)

\begin{tabular}{|c|c|c|c|c|c|c|}
\hline $\begin{array}{l}\text { Variables } \\
\text { (abbreviation) }\end{array}$ & Mean & SD & Min. & Max. & Measurement & $\begin{array}{c}\text { Source of } \\
\text { data }\end{array}$ \\
\hline \multicolumn{7}{|c|}{ Institutional Quality Indicator (IQ) } \\
\hline External Debt Policy & 3.62 & 0.78 & 1 & 6 & $\begin{array}{l}1=\text { low quality } \\
6=\text { high quality }\end{array}$ & $\begin{array}{c}\text { CPIA, } \\
\text { World } \\
\text { Bank }\end{array}$ \\
\hline $\begin{array}{l}\text { Economic Management } \\
\text { Cluster }\end{array}$ & 3.65 & 0.58 & 1.83 & 5.5 & $\begin{array}{l}1=\text { low } \\
6=\text { high }\end{array}$ & $\begin{array}{c}\text { CPIA, } \\
\text { World } \\
\text { Bank }\end{array}$ \\
\hline $\begin{array}{l}\text { Macroeconomic } \\
\text { Management }\end{array}$ & 3.81 & 0.55 & 2 & 5.5 & $\begin{array}{l}1=\text { low } \\
6=\text { high }\end{array}$ & $\begin{array}{c}\text { CPIA, } \\
\text { World } \\
\text { Bank }\end{array}$ \\
\hline
\end{tabular}

Over the period 2005 to 2016 on average, countries held more than $50 \%$ of their external debt in the form of public external debt, thus highlighting the importance of analyzing the role of institutional quality in the external debt-growth relationship. That is, at high levels of external debt holding, does institutional quality matter? Figure 1 shows a scatter diagram of external debt versus GDP per capita growth for the 53 countries using data averages from 2005 to 2016. Countries that hold over $60 \%$ (of GNI) as external debt, such as the Republic of Congo and Gambia, experience less than 2\% in GDP per capita growth. Meanwhile, Bhutan, Georgia, Lao PDR, and Mongolia are among those countries that hold an external debt of more than $60 \%$ of GNI and are associated with a high GDP per capita growth (i.e. they experienced, at least, $6 \%$ of growth). Thus, having a higher debt is associated with higher growth for most countries in our sample. This could highlight possible benefits for the countries holding external debt.

The results on the effects of external debt and institutional on a country's growth are shown in Table 3. Our analysis starts by examining the impact of external debt on growth, as shown in column 2 (Model 1a). The results reveal that external debt has a negative impact on growth, which is consistent with previous studies (Cordella et al., 2010; Pattillo et al., 2011; Ramzan and Ahmad, 2014; Daud and Podivinsky, 2012; Choong et al., 2010; Pattillo et al., 2004; Chowdhury, 2001; Sen et al., 2007). Considering the other three models (i.e. Models b, c, and d), the slope coefficient on external debt is statistically significant and is in the 0.07 to 0.08 range, suggesting a decline in growth of at least $0.07 \%$ for a percentage change in external debt. The control variables show the correct signs and are significant at the 5\% significance level, at least. In addition, the main model could not reject the null hypothesis of no second-order serial correlation at the $5 \%$ significance level, at least. Besides that, the $p$-value of 0.90 generated by the Sargan test suggests that we could not reject the null hypothesis of no over-identifying restriction for the estimation. This shows that the instrument variables in our system GMM estimations are valid. 
Figure 1.

External Debt Versus GDP per Capita Growth

The figure plots a scatter diagram of external debt versus GDP per capita growth for 53 countries using data averages from 2005 to 2016.

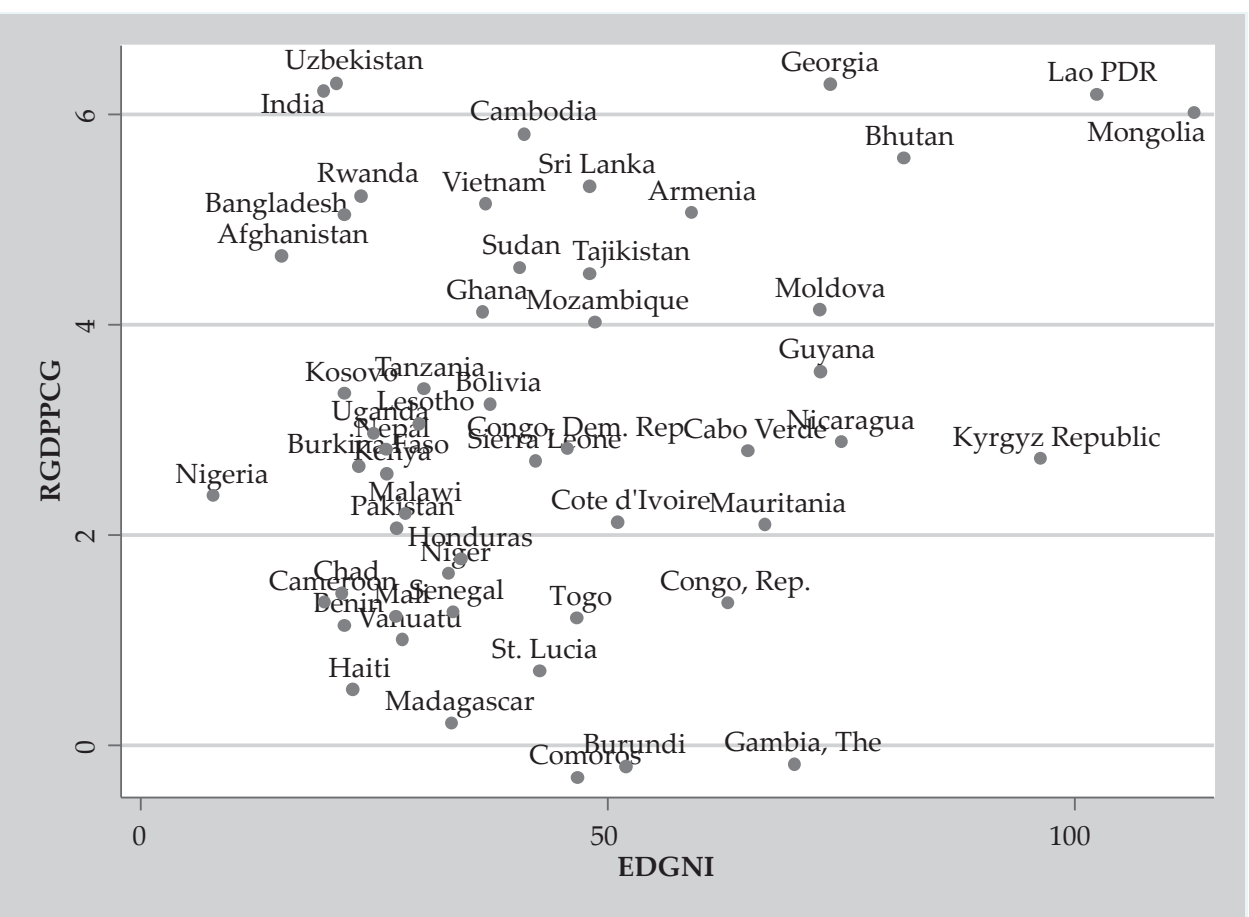

Table 3.

\section{Results on GMM-System Estimation on External Debt, Institutional Quality and Economic Growth}

This table shows the relationship between external debt, institutional quality and economic growth. The baseline results on the effect of external on country economic growth is present in column 2 (model 1a). In addition, model $1 \mathrm{~b}$, $1 \mathrm{c}$ and $1 \mathrm{~d}$ present the results of debt-growth model with the inclusion of institutional quality variable namely external debt policy, economic management cluster and macroeconomic management respectively. Notes: ${ }^{* * *}, * *$ and ${ }^{*}$ denote significant at $1 \%, 5 \%$, and $10 \%$. Statistics in parenthesis denote the $t$-statistics.

\begin{tabular}{lcccc}
\hline GROWTH & Model 1a & Model 1b & Model 1c & Model 1d \\
\cline { 2 - 5 } Main model & $\begin{array}{c}\text { Institutional } \\
\text { indicator: } \\
\text { External debt } \\
\text { policy }\end{array}$ & $\begin{array}{c}\text { Institutional } \\
\text { indicator: } \\
\text { Economic } \\
\text { management } \\
\text { cluster }\end{array}$ & $\begin{array}{c}\text { Institutional } \\
\text { indicator: } \\
\text { Macroeconomic } \\
\text { management }\end{array}$ \\
\hline Initial income & $0.00^{* * *}$ & $0.00^{* * *}$ & $0.00^{* * *}$ & $0.00^{* * *}$ \\
Investment & $(18.74)$ & $(15.75)$ & $(15.80)$ & $(16.94)$ \\
Population growth & $0.09^{* * *}$ & $0.08^{* * *}$ & $0.08^{* * *}$ & $0.08^{* * *}$ \\
& $(11.75)$ & $(13.59)$ & $(8.52)$ & $(9.12)$ \\
& $0.84^{* * *}$ & $1.67^{* * *}$ & $1.75^{* * *}$ & $1.09^{* * *}$ \\
\hline
\end{tabular}


Table 3.

Results on GMM-System Estimation on External Debt, Institutional Quality and Economic Growth (Continued)

\begin{tabular}{lcccc}
\hline GROWTH & Model 1a & Model 1b & Model 1c & Model 1d \\
\cline { 2 - 5 } & Main model & $\begin{array}{c}\text { Institutional } \\
\text { indicator: } \\
\text { External debt } \\
\text { policy }\end{array}$ & $\begin{array}{c}\text { Institutional } \\
\text { indicator: } \\
\text { Economic } \\
\text { management } \\
\text { cluster }\end{array}$ & $\begin{array}{c}\text { Institutional } \\
\text { indicator: } \\
\text { Macroeconomic } \\
\text { management }\end{array}$ \\
\hline Trade & $0.06^{* * *}$ & $0.04^{* * *}$ & $0.05^{* * *}$ & $0.05^{* * *}$ \\
ED & $(18.22)$ & $(9.48)$ & $(8.17)$ & $(11.73)$ \\
IQ & $-0.08^{* * *}$ & $-0.07^{* * *}$ & $-0.07^{* * *}$ & $-0.08^{* * *}$ \\
Constant & $(21.24)$ & $(20.26)$ & $(22.02)$ & $(18.49)$ \\
& & $2.05^{* * *}$ & $2.05^{* * *}$ & $0.61^{* * *}$ \\
AR(2) test (p-value) & $(16.59)$ & $(9.80)$ & $(4.66)$ \\
Sargan test (p-value) & $-5.57^{* * *}$ & $-13.86^{* * *}$ & $-14.65^{* * *}$ & $-8.02^{* * *}$ \\
\hline
\end{tabular}

A negative effect of external debt on growth, as reported in recent and previous studies leads to the possible existence of a contingency effect of external debt on economic growth. Before analyzing the contingency effect of institutions on the effect of external debt on economic growth, we analyze the effect of institutions on growth and report the results in columns 2 to 4 of Table 3 (i.e., we estimate Models $1 b$, c, and d, respectively). The three institutional quality variables have a positive and statistically significant impact on economic growth, meaning that institutions positively contribute to economic growth, which is consistent with several studies (see, e.g., Mensah et al., 2018; Cordella et al., 2010; Presbitero, 2008; Imbs and Ranciere, 2005). However, with the inclusion of the institutional indicator in the external debt-growth nexus specification, external debt consistently contributed negatively and significantly to growth, at least, at the 5\% significance level (i.e. Models $1 \mathrm{~b}, \mathrm{c}$, and $\mathrm{d}$ ), based on the $p$-values, we could not reject the null of no second-order serial correlation for the AR(2) test for these models. The Sargan test also could not reject the null hypothesis of no over-identifying restriction, suggesting that the instruments are valid.

We further extended our analysis to consider the contingency effect of institutional quality on the external debt-growth nexus. Intuitively, since external debt also involved equal representation of private and government borrowing, institutional quality matters in ensuring the efficient allocation and distributions of debt to targeted sectors and specifically formulated policies. We follow Mensah et al.'s (2018) approach and report our results in Table 4. The results show that the interaction terms between external debt and the institutional quality variables are significant at the 5\% significance level, implying that the effect of external debt on economic growth depends on the level of institutional quality. However, 
the negative sign of the interaction terms would lead to the argument regarding why external debt affects a country's economic growth negatively as institutional quality improved.

Table 4.

Results on GMM-System Estimation on External Debt, Institutional Quality and Economic Growth (Interaction Between Institutional Indicator and External Debt Variable)

This table present results of the interaction between institutional quality variable and external debt variable. Notes: $* * * * * *$ and ${ }^{*}$ denote significant at $1 \%, 5 \%$ and $10 \%$. Statistics in parenthesis denote the $t$-statistics.

\begin{tabular}{lccc}
\hline \multirow{2}{*}{ GROWTH } & Model 2a & Model 2b & Model 2c \\
\cline { 2 - 4 } & $\begin{array}{c}\text { Institutional } \\
\text { indicator: External } \\
\text { debt policy }\end{array}$ & $\begin{array}{c}\text { Institutional } \\
\text { indicator: Economic } \\
\text { management cluster }\end{array}$ & $\begin{array}{c}\text { Institutional } \\
\text { indicator: } \\
\text { Macroeconomic } \\
\text { management }\end{array}$ \\
\hline Initial Income & $0.00^{* * *}$ & $0.00^{* * *}$ & $0.00^{* * *}$ \\
Investment & $(19.99)$ & $(22.38)$ & $(9.61)$ \\
Population Growth & $0.08^{* * *}$ & $0.09^{* * *}$ & $0.09^{* * *}$ \\
Trade & $(10.95)$ & $(12.12)$ & $(13.29)$ \\
& $1.58^{* *}$ & $1.74^{* * *}$ & $1.14^{* * *}$ \\
ED & $(6.54)$ & $(6.03)$ & $(4.69)$ \\
IQ & $0.05^{* * *}$ & $0.05^{* * *}$ & $0.06^{* * *}$ \\
& $(9.79)$ & $(10.95)$ & $(8.25)$ \\
ED*IQ & 0.01 & $0.06^{* * *}$ & $0.08^{* * *}$ \\
& $(1.26)$ & $(4.26)$ & $(6.28)$ \\
Constant & 3.00 & $3.71^{* * *}$ & $2.46^{* * *}$ \\
AR(2) test (p-value) & $(12.64)$ & $(10.73)$ & $(14.31$ \\
Sargan test (p-value) & $-0.03^{* * *}$ & $-0.04^{* * *}$ & $-0.04^{* * *}$ \\
\hline
\end{tabular}

The other explanatory variables show a consistent effect on economic growth at the $5 \%$ significance level. The $p$-values for the serial correlation test suggest that we could not reject the null of no second-order serial correlation. The Sargan test also fails to reject the null hypothesis of no over-identifying restriction, suggesting that the instruments are valid.

To further investigate the negative effect of the interaction term (i.e. interaction between external debt and institutional quality), we explore possible threshold levels of external debt and institutional quality using a dynamic panel threshold regression. Table 5 shows the results using the three institutional indicators. In Model 3a, where the external debt is a threshold variable, the threshold level of 
external debt as a percentage of GNI is $46.56 \%$ with a $95 \%$ confidence interval of [29.28, 54.45]. External debt has an insignificant effect on growth below the threshold value (see Panel B of Table 5). However, the effect of external debt on economic growth becomes negative after this threshold value is surpassed. By carefully looking at our data, we observed that external debt surpassed the threshold of $46.56 \%$ in 214 out of the 636 periods ( $t$ ). Armenia, Burundi, Bhutan, Bolivia, Comoros, Congo, Democrat Republic, Cabo Verde, Cambodia, Congo Republic, Cote d'Ivoire, Guyana, Georgia, Ghana, Gambia, Kyrgyz Republic, Lao, Madagascar, Malawi, Mali, Mozambique, Mauritania, Moldova, Mongolia, Nicaragua, Niger, Rwanda, Sierra Leone, Sri Lanka, Sudan, Tajikistan, St. Lucia, Togo, Uganda, and Vanuatu experienced, at least, one period where external debt holding surpassed the threshold level. Meanwhile, for Models 3b, 3c, and 3d, where the institutional quality indicator is the threshold variable, the threshold value lies within 3 to 4.5 index points. Since institutional quality is defined such that 1 and 6 denote, respectively, low and high institutional quality, the threshold values imply that below 3 and above 4.5 denote, respectively, low and high institutional quality.

The impact of external debt on growth is negative but insignificant when institutional quality threshold is below 3.00, while the effect becomes significant above this threshold(see Models $3 b$ and $3 d$, and Model 3c), thus suggesting that the negative effect of external debt on economic growth is non-monotonic, since it depends on the level of institutional quality. In other words, as institutional quality improves, the negative effect of external debt on growth becomes important, consistent with Cordella et al. (2010), who found that countries with good policies and institutions still experience the negative effect of external debt as the debt level rises above 25\% of GDP. Unlike Cordella et al. (2010), we find that the negative effect of external debt sets in when external debt exceed $45.56 \%$ of GNI.

Table 5.

\section{Results of Dynamic Panel Threshold Estimation with External Debt and Institutional Quality Indicators as A Threshold Variable}

This table shows the robustness test of the external debt and institutional quality on economic growth by employing the dynamic panel threshold estimates. Notes: ${ }^{* * *},{ }^{* *}$ and ${ }^{*}$ denote significant at $1 \%, 5 \%$, and $10 \%$. Statistics in parenthesis denote the t-statistics.

\begin{tabular}{ccccc}
\hline Panel A: Threshold variable & Model 3a & Model 3b & Model 3c & Model 3d \\
\cline { 2 - 5 } & $\begin{array}{c}\text { External debt to } \\
\text { GNI }\end{array}$ & $\begin{array}{c}\text { Institutional } \\
\text { indicator: } \\
\text { External debt } \\
\text { policy }\end{array}$ & $\begin{array}{c}\text { Institutional } \\
\text { indicator: } \\
\text { Economic } \\
\text { management } \\
\text { cluster }\end{array}$ & $\begin{array}{c}\text { Institutional } \\
\text { indicator: } \\
\text { Macroeconomic } \\
\text { management }\end{array}$ \\
\hline Threshold estimates, $\hat{\lambda}$ & 46.56 & 4.50 & 3.00 & 4.50 \\
$95 \%$ confidence interval & {$[29.28,54.45]$} & {$[4.50,4.50]$} & {$[3.00,3.33]$} & {$[3.00,4.50]$} \\
\hline \multirow{3}{*}{$\widehat{\beta_{1}}$} & Panel B: Impact of external debt on growth & -0.00 & $-0.02^{* *}$ \\
\hline$\widehat{\beta_{2}}$ & 0.02 & $-0.02^{* *}$ & $(0.36)$ & $(4.34)$ \\
\hline
\end{tabular}


Table 5.

Results of Dynamic Panel Threshold Estimation with External Debt and Institutional Quality Indicators as A Threshold Variable (Continued)

\begin{tabular}{|c|c|c|c|c|}
\hline \multirow[t]{2}{*}{ Panel A: Threshold variable } & Model 3a & Model 3b & Model 3c & Model 3d \\
\hline & $\begin{array}{l}\text { External debt to } \\
\text { GNI }\end{array}$ & $\begin{array}{l}\text { Institutional } \\
\text { indicator: } \\
\text { External debt } \\
\text { policy }\end{array}$ & $\begin{array}{l}\text { Institutional } \\
\text { indicator: } \\
\text { Economic } \\
\text { management } \\
\text { cluster }\end{array}$ & $\begin{array}{l}\text { Institutional } \\
\text { indicator: } \\
\text { Macroeconomi } \\
\text { management }\end{array}$ \\
\hline \multicolumn{5}{|c|}{ Panel C: Impact of covariates } \\
\hline \multirow[t]{2}{*}{ Initial income $_{\mathrm{it}-1}$} & $-6.38^{* *}$ & $-4.71^{* *}$ & $-4.67^{* *}$ & $-5.55^{* *}$ \\
\hline & $(4.59)$ & $(3.54)$ & $(3.22)$ & $(4.32)$ \\
\hline \multirow[t]{2}{*}{ Investment $_{\text {it }}$} & $0.08^{* *}$ & $0.07^{* *}$ & $0.07^{*}$ & $0.08^{* *}$ \\
\hline & $(2.09)$ & $(1.97)$ & $(1.72)$ & $(2.11)$ \\
\hline \multirow[t]{2}{*}{ Population growth $_{\text {it }}$} & 0.50 & 0.91 & 0.24 & 0.39 \\
\hline & $(0.69)$ & $(1.49)$ & $(0.33)$ & $(0.68)$ \\
\hline \multirow[t]{3}{*}{ Trade $_{\text {it }}$} & 0.02 & $0.03^{* *}$ & $0.02^{*}$ & $0.02^{* *}$ \\
\hline & $(1.39)$ & $(2.07)$ & $(1.71)$ & $(1.85)$ \\
\hline & 0.91 & $-8.86^{* *}$ & $-3.16^{* *}$ & $-15.27^{*}$ \\
\hline$\widehat{\delta_{1}}$ & $(0.66)$ & $(2.08)$ & (2.92) & $(1.67)$ \\
\hline
\end{tabular}

\section{CONCLUSION}

In this paper, we examine the effect of institutional quality and external debt on economic growth, while controlling for the traditional determinants of growth. An important way our work is different from the literature is that we estimate and model the threshold level of debt required for an economy to optimize the effect of debt on growth. We add to this analysis a search for the threshold level of institutional quality. We examine the way external debt and institutions interact, and test how these parameters influence the impact of external debt on growth. Our hypothesis is that, while external debt and institutional quality negatively and positively affect growth, respectively, their interaction should have a moderating effect on growth. In addition, as institutional quality improves, the effect of debt on growth should be positive. We find that, as institutional quality improves, the negative effect of debt on economic growth holds true. Specifically, we estimate that the negative impact of external debt on growth is relevant as external debt exceeds $46.56 \%$ of GNI. A fortiori, the accumulated external debt level needs to be reduced to a prudent level where good institutional quality could positively complement the effect of external debt on a country's growth.

\section{Acknowledgement}

The authors thank the editor Prof. Paresh Kumar Narayan and anonymous referee(s) for providing valuable suggestions, which improved this paper substantially. The usual disclaimer applies. 


\section{REFERENCE}

Agbloyor, E. K., Abor, J.Y., Adjasi, C.K.D., and Yawson, A. (2014). Private Capital Flows and Economic Growth in Africa: The Role of Domestic Financial Markets. Journal of International Financial Markets, Institutions and Money, 30, 137-152.

Alfaro, L., Chanda, A., Kalemli-Ozcan, S., and Sayek, S. (2004). FDI and Economic Growth: The Role of Local Financial Market, Journal of International Economics, 64, 113-134.

Arellano, M., and Bond, S. (1991). Some Test of Specification for Panel Data: Monte Carlo Evidence and an Application to Employement Equation. Review of Economics Studies, 58, 277-297.

Arellano, M., and Bover, O. (1995). Another Look at the Instrumental Variables Estimation of Error-Components Models. Journal of Econometrics, 68, 29-51.

Bailliu, J.N. (2000). Private Capital Flows, Financial Development and Economic Growth in Developing Countries, Bank of Canada Working Paper no.15.

Brambila-Macias, J., and Massa, I. (2010). The Global Financial Crisis and Subsaharan Africa: The Effects of Slowing Private Capital Inflows on Growth. African Development Revie, 22, 366-377.

Blundell, R., and Bond, S. (1998). Initial Conditions and Moment Restrictions in Dynamic Panel Data Models. Journal of Econometrics, 87, 115-143.

Chowdhury, A.R. (2001). External Debt and Growth in Developing Countries: A Sensitivity and Causal Analysis. WIDER Discussion Paper No. 2001/95.

Clements, B., Bhattacharya, R., and Nguyen, T.Q. (2003). External Debt, Public Investment and Growth in Low-Income Countries. IMF Working Paper No. 03/249.

Cordella, T., Ricci, L.A., and Ruiz-Arranz, M. (2010). External Debt Overhang of External Debt Irrelevance? IMF Staff Paper, 57, 1-24.

Daud, S.N.M., and Podivinsky, J.M. (2014). Government Debt and Economic Growth in Malaysia: The Role of Institutional Quality. Applied Economics Letters, 21, 1179-1183.

Daud, S.N.M., and Podivinsky, J.M. (2012). Revisiting the Role of External Debt in Economic Growth of Developing Countries. Journal of Business, Economics and Management, 13, 968-993.

Dawson, JW. (2003). Causality in the Freedom-Growth Relationship. European Journal of Political Economy, 19, 479-495.

Devpura, N., and Narayan, P.K., (2020) Hourly Oil Price Volatility: The Role of COVID-19, Energy Research Letters, 1(2), 13683. https://doi. org/10.46557/001c.13683

Fu, M., \& Shen, H. (2020). COVID-19 and corporate performance in the energy industry. Energy Research Letters, 1(1), 12967.https://doi.org/10.46557/001c.12967

Griffin, K.B., and Enos, J.L. (1970). Foreign Assistance: Objectives and Consequences. Economic Development and Cultural Change, 18, 313-327.

Gwartney, J.D., Holcombe, R.G., and Lawson, R.A. (2004). Economic Freedom, Institutional Quality, and Cross-Country Differences in Income and Growth. Cato Journal 24, 205-233.

Hansen, B.E. (2000). Sample Splitting and Threshold Estimation. Econometrica, 68, 575-603. 
Haroon, O., and Rizvi, S.A.R., (2020) Flatten the Curve and Stock Market Liquidity-An Inquiry into Emerging Economies. Emerging Markets Finance and Trade, 56, 2151-2161; https://doi.org/10.1080/1540496X.2020.1784716.

Heckelman, J.C., and Stroup, M.D. (2000). Which Economic Freedom Contributes to Growth? Kyklos, 53, 527-544.

Heckelman, J.C. (2000). Economic Freedom and Economic Growth: A Short-Run Causal Investigation. Journal of Applied Economics, 3, 71-91.

Ho, S. Y., \& Iyke, B. N. (2020). The Determinants of Economic Growth in Ghana: New Empirical Evidence. Global Business Review, 21, 626-644.

Imbs, J., and Ranciere, R. (2005). The Overhang Hangover, World Bank Policy Research Working Paper No. 3673.

International Monetary Fund (IMF). (2019). IMF Annual Report 2019: Our Connected World. International Monetary Fund, Washington, United States.

Iyke, B. N. (2017). Does Trade Openness Matter for Economic Growth in the CEE Countries?. Review of Economic Perspectives, 17, 3-24.

Iyke, B. N. (2018). The Real Effect of Currency Misalignment on Productivity Growth: Evidence from Middle-Income Economies. Empirical Economics, 55, 1637-1659.

Iyke, B.N., (2020a) The Disease Outbreak Channel of Exchange Rate Return Predictability: Evidence from COVID-19, Emerging Markets Finance and Trade, 56, 2277-2297; https://doi.org/10.1080/1540496X.2020.1784718.

Iyke,B.,(2020b)COVID-19:TheReaction ofUSOiland GasProducerstothePandemic, Energy Research Letters, 1(2), 13912. https://doi.org/10.46557/001c.13912

Juhro, S. M., Narayan, P. K., Iyke, B. N., \& Trisnanto, B. (2020). Is There a Role for Islamic Finance and R\&D in Endogenous Growth Models in the Case of Indonesia?. Pacific-Basin Finance Journal, 101297. https://doi.org/10.1016/j. pacfin.2020.101297.

Kremer. S., Bick, A., and Nautz, D. (2012). Inflation and Growth: New Evidence from a Dynamic Panel Threshold Analysis, Empirical Economics, 44, 861-878.

Kirch, G., and Terra, P.R.S. (2012). Determinant of Corporate External Debt Maturtiy in South America: Do Instituional Quality and Financial Development Matter?, Journal of Corporate Finance, 18, 980-993.

Law, S.H., Kutan, A.M., and Naseem, N.A.M. (2018). The Rolw of Instituitions in Finance Curse: Evidence from International Data. Journal of Comparative Economics, 46,174-191.

Law, S.H., W.N.W. Azman-Saini and Ibrahim, M. (2013). Institutional Quality Threshold and the Finance-Growth Nexus. Journal of Banking and Finance, 37, 5373-5381.

Mensah, D., Aboagye, A., Abor, J., and Kyereboah-Coleman, A. (2018a). External Debt Among HIPC's in Africa: Accounting and Panel VAR Analysis of Some Determinants, Journal of Economics Studies, 44, 431-455.

Mensah, D., Bokpin, G., and Boachie-Yiadom, E. (2018b). External Debts, Instituion and Growth in SSA. Journal of African Business, 9, 457-490.

Mishra, A.K., Rath, B.N., and Dash, A.K., (2020) Does the Indian Financial Market Nosedive Because of the COVID-19 Outbreak, in Comparison to After Demonetisation and the GST? Emerging Markets Finance and Trade, 56, 21622180; https://doi.org/10/1080/1540496X.2020.1785425. 
Narayan, P. K. (2020). Oil price news and COVID-19-Is there any connection?. Energy Research Letters, 1(1), 13176. https://doi.org/10.46557/001c.13176

Otani, I., Villaneuva, D. (1989). Theoretical Aspects of Growth in Developing Countries: External Debt Dynamic and the Role of Human Capital. IMF Staff Paper, 36, 307-342.

Ouyang, A.Y., and Rajan, R.S. (2014). What Determines External Debt Tipping Points? Journal of. Macroeconomics, 39, 215-225.

Pattillo, C., Poirson, H., and Ricci, L.A. (2011). External Debt and Growth. Review of Economics and Institutions, 2, 1-30.

Pattillo, C., Poirson, H., and Ricci, L. (2004). What Are the Channels Through Which External Debt Affects Growth? IMF Working Paper No. 04/15.

Phan, D.H.B., and Narayan, P.K. (2020). Country responses and the reaction of the stock market to COVID-19-a Preliminary Exposition. Emerging Markets Finance and Trade, 56, 2138-2150; https://doi.org/10.1080/1540496X.2020.1784719'

Prabheesh, K.P., Padhan, R., and Garg, B. (2020). COVID-19 and the Oil PriceStock Market Nexus: Evidence from Net Oil-Importing Countries, Energy Research Letters, 1(2), 13745. https://doi.org/10.46557/001c.13745

Ramzan, M., and Ahmad, E. (2014). External Debt Growth Nexus: Role of Macroeconomic Policies. Economic Modelling, 38, 204-210.

Salisu, A., \& Adediran, I. (2020). Uncertainty due to infectious diseases and energy market volatility Energy Research Letters, 1(2), 14185. https://doi. org/10.46557/001c.14185

Sen, S., Kasibhatla, M., and Stewart, D.B. (2007). External Debt Overhang and Economic Growth-The Asian and the Latin America Experiences. Economics System, 31, 3-11.

Takumah, W., \& Iyke, B. N. (2017). The Links between Economic Growth and Tax Revenue in Ghana: an Empirical Investigation. International Journal of Sustainable Economy, 9, 34-55.

United Nations Economic and Social Council Economic Commission for Africa (UNECA), (2012). Impact of the European External Debt Crisis on Africa's Economy, UNECA background paper, United Nations Economic and Social Council Economic Commission for Africa, Ethiopia.

Vidya, C. T., and Prabheesh, K.P. (2020). Implications of COVID-19 Pandemic on the Global Trade Networks. Emerging Markets Finance and Trade, 56, 2408-2421 https://doi.org/10.1080/1540496X.2020.1785426.

Villaneuva, D. (2003). External Debt, Capital Accumulation and Growth, SMU-SESS Discussion Paper Series in Economic Studies. 


\section{APPENDIX}

\section{Appendix 1.}

\section{List of 53 countries}

List of the countries are presented in this table. We have 53 countries.

\begin{tabular}{llllll}
\hline Afghanistan & Armenia & Benin & Burkina Faso & Burundi & Bangladesh \\
Bhutan & Bolivia & Chad & Comoros & Congo, Dem & Cabo Verde \\
Cambodia & Cameroon & Congo, Rep. & Cote d'Ivoire & Guyana & Georgia \\
Ghana & Honduras & Gambia & Haiti & India & Kenya \\
Kosovo & Kyrgyz & Lao PDR & Lesotho & Madagascar & Malawi \\
Mali & Mozambique & Mauritania & Moldova & Mongolia & Nicaragua \\
Nigeria & Nepal & Niger & Pakistan & Rwanda & Senegal \\
Sierra Leone & Sri Lanka & Sudan & Tajikistan & St Lucia & Tanzania \\
Togo & Uganda & Uzbekistan & Vanuatu & Vietnam & \\
\hline
\end{tabular}

